\title{
INGENIUM OMNIA VINCIT
}

\section{HUGH MACDIARMID}

'The stream has suddenly pushed the papery leaves!

It digs a rustling channel of clear water

On the scarred flank of Ben Bulben,

The twisted tree is incandescent with flowers.

The swan leaps singing into the cold air...'

A. J. M. SMITH

\begin{abstract}
WThat are the words on that stone? Pilate's words which are the finest rejoinder in all literature to the captious and disputatious: What I have written I have written.
\end{abstract}

Earth has nowhere any grave so deep

As the power of utter withdrawal

Into yourself you had, and Death

no power to restore to life again

like your power, still and forever, to come back

Full of brio as if never away

and laughing like a better Lazarus.

(You who knew if Christ had made even one

Joke about sex what vast good He'd have done !)

What is the secret? You never breathed her name

But the old woman in Euboea was your Muse

Whose lesson to man is not to abstract himself

From immersion in present experience.

So out of death arises fresh life, even as Kenelm's corpse

Touched off springs where it rested. So you practised her rites

That ward off the menace of death

And ensure that life be strong and vigorous

And no song ever a swan-song. 